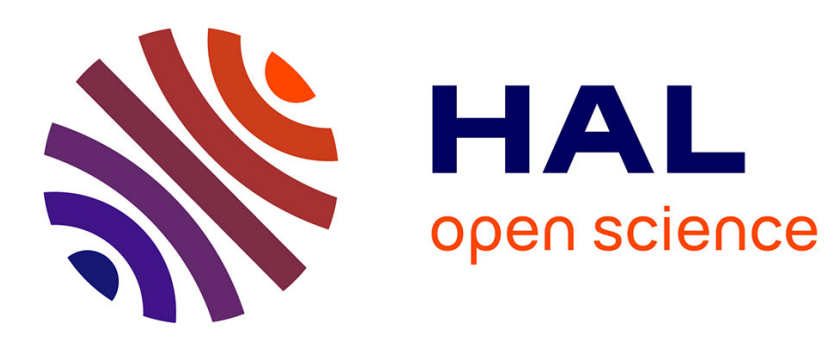

\title{
Will the asthma revolution fostered by biologics also benefit adult ICU patients?
}

Arnaud Bourdin, Jérémy Charriot, Clément Boissin, Engi Ahmed, Carey

Suehs, Arthur de Sevin, Mathilde Volpato, Laurie Pahus, Delphine Gras, Isabelle Vachier, et al.

\section{To cite this version:}

Arnaud Bourdin, Jérémy Charriot, Clément Boissin, Engi Ahmed, Carey Suehs, et al.. Will the asthma revolution fostered by biologics also benefit adult ICU patients?. Allergy, 2021, 76 (8), 10.1111/all.14688. hal-03044172

HAL Id: hal-03044172

https://hal.science/hal-03044172

Submitted on 28 Jul 2021

HAL is a multi-disciplinary open access archive for the deposit and dissemination of scientific research documents, whether they are published or not. The documents may come from teaching and research institutions in France or abroad, or from public or private research centers.
L'archive ouverte pluridisciplinaire HAL, est destinée au dépôt et à la diffusion de documents scientifiques de niveau recherche, publiés ou non, émanant des établissements d'enseignement et de recherche français ou étrangers, des laboratoires publics ou privés. 


\title{
Will the asthma revolution fostered by biologics also benefit adult ICU patients?
}

\author{
Arnaud Bourdin $^{1,2}$, | Jérémy Charriot ${ }^{1,2}$ | Clément Boissin ${ }^{1}$ | Engi Ahmed ${ }^{1}$ | \\ Carey Suehs $^{1,3}$ | Arthur De Sevin ${ }^{1}$ | Mathilde Volpato ${ }^{1}$ | Laurie Pahus ${ }^{4,5,6}$ | \\ Delphine Gras $^{6}$ | Isabelle Vachier ${ }^{1}$ | Laurence Halimi $^{1}$ | Dominic Hamerlijnck ${ }^{7}$ | \\ Pascal Chanez ${ }^{4,6}$
}

\author{
${ }^{1}$ Department of Respiratory Diseases, \\ Univ Montpellier, CHU Montpellier, \\ Montpellier, France \\ ${ }^{2}$ PhyMedExp, Univ Montpellier, CNRS, \\ INSERM, CHU Montpellier, Montpellier, \\ France \\ ${ }^{3}$ Department of Medical Information, \\ Univ Montpellier, CHU Montpellier, \\ Montpellier, France \\ ${ }^{4}$ Aix Marseille Univ, APHM, Hôpital \\ NORD, CIC 9502, Clinique des bronches \\ allergies et sommeil, Chemin des Bourrely, \\ 13015, Marseille, France \\ ${ }^{5}$ Aix Marseille Univ, CNRS, EFS, ADES, \\ Marseille, France \\ ${ }^{6}$ Aix Marseille Univ, INSERM U1263, INRA \\ 1260 (C2VN), Marseille, France \\ ${ }^{7}$ Dutch Lung Foundation, Amersfoort, The \\ Netherlands
}

\section{Correspondence}

Arnaud Bourdin, Département de Pneumologie et Addictologie, PhyMedExp, University of Montpellier, INSERM U1046, CNRS UMR 9214, Hôpital Arnaud de Villeneuve, CHU Montpellier - France. Email: a-bourdin@chu-montpellier.fr

\begin{abstract}
Purpose: Asthma exacerbations are inflammatory events that rarely result in full hospitalization following an ER visit. Unfortunately, certain patients require prolonged support, including occasional external lung support through ECMO or ECCOR (with subsequent further exposure to other life-threatening issues), and some die. In parallel, biologics are revolutionizing severe asthma management, mostly in $\mathrm{T} 2$ high patients. Methods: We extensively reviewed the current unmet needs surrounding ICUadmitted asthma exacerbations, with a focus on currently available drugs and the underlying biological processes involved. We explored whether currently available T2-targeting drugs can reasonably be seen as potential players not only for relapse prevention but also as candidate drugs for a faster resolution of such episodes. The patient's perspective was also sought.

Results: About $30 \%$ of asthma exacerbations admitted to the ICU do not resolve within five days. Persistent severe airway obstruction despite massive doses of corticosteroids and maximal pharmacologically induced bronchodilation is the main cause of treatment failure. Previous ICU admission is the main risk factor for such episodes and may eventually be considered as a T2 surrogate marker. Fatal asthma cases are hallmarked by poorly steroid-sensitive $\mathrm{T} 2$-inflammation associated with severe mucus plugging. New, fast-acting T2-targeting biologics (already used for preventing asthma exacerbations) have the potential to circumvent steroid sensitivity pathways and decrease mucus plugging. This unmet need was confirmed by patients who reported highly negative, traumatizing experiences.

Conclusions: There is room for improvement in the management of ICU-admitted severe asthma episodes. Clinical trials assessing how biologics might improve ICU outcomes are direly needed.

KEYWORDS

asthma, IL4Ralpha, IL5, severe exacerbation, T2 airway inflammation
\end{abstract}




\section{1 | INTRODUCTION}

Decreasing asthma admissions and mortality are currently attributed primarily to increased disease awareness and improved inhaled corticosteroid (ICS) availability worldwide. ${ }^{1,2}$ The development of new anti-asthma drugs has focused on moderate to severe exacerbations, which represent a majority of the asthma disease burden due to their immediate and future associated-risks. ${ }^{3-5}$ Work impairment, presence and sick-leave, emergency room (ER) visits and admissions, intensive care unit (ICU) admissions, and death can all be directly related to an acute episode of airway obstruction. They can also be indirectly linked to the aggravation of severe episodes because of associated or treatment-induced comorbidities (such as diabetes mellitus, hypertension, tachycardia, and atrial fibrillation). Future risks are mostly related to oral corticosteroid (OCS)-related side effects. ${ }^{6-8}$

Regarding exacerbations, severe asthma attacks involving the ICU are presently attributed to poor ICS adherence resulting in beta-2 agonist overuse, and other known causes of poor corticosteroid response (such as, for example, obesity or cigarette and cannabis smoking or drug abuse). ${ }^{9-16}$ However, a tangible fraction of admissions and death remain insufficiently explained by these criteria., ${ }^{77-19}$ The extremities of the T2 airway inflammation spectrum are poorly steroid-sensitive ${ }^{20}$ and have led to the development of new anti-asthma drugs. Severe and steroid-refractory T2-inflammation is currently well addressed by IL5 and IL4-IL13 targeting drugs, whereas T2-low asthmatics-also poorly steroid-sensitive-are currently waiting for an appropriately targeted intervention. FDA approvals for biologics mention in the "Limitations of use" that these drugs are "Not for relief of acute bronchospasm or status asthmaticus". ${ }^{21-25}$

Asthma patient trajectories leading to intensive care are unfortunately hallmarked by relapse. Beyond willingness to improve the awareness of intensivists concerning new medications demonstrated to prevent severe exacerbations, ${ }^{17-19,26-30}$ the present review aims to better characterize the burden of severe exacerbations resulting in ICU admission and the current unmet needs related to these episodes, including the patients' point-of-view. Deciphering the underlying mechanisms involved in these episodes and juxtaposing this knowledge with the mechanisms of action known for standard and biological anti-asthma therapies may help elucidate useful ICU-concomitant indications.

\section{2 | PATHOBIOLOGY OF FATAL AND NEAR-FATAL ASTHMA}

Autopsy studies revolutionized the understanding of fatal asthma episodes. ${ }^{31,32}$ Luckily, they are rare. However, the relative paucity of cases often results in the imperfect characterization of the exact clinical circumstances associated with death. Nevertheless, such insight is invaluable for evaluating the relative contributions of the potential contributing factors involved in these tragic episodes. Dying from a fatal asthma episode undoubtedly denotes particularities either in the intensity or the nature of the airway obstruction.
Not all asthmatics exposed to toxic substances such as heroin or who are absolutely not adherent to their treatment will ever experience such an episode. Coupling metacholine-induced ventilatory mismatches with mathematical models emphasized the mandatory involvement of small airway obstruction in near-fatal asthma episodes, with certain such episodes eventually rescued thanks to regional disparities within the lung. ${ }^{33}$ Accordingly, most efforts were then concentrated on assessing the contribution of small airways to overall airway obstruction. It was shown that although their relative contribution was smaller at steady state than the proximal airways, a fivefold to 10 -fold increase in small airway resistance made them by far the main contributor to near-fatal asthma (NFA) episodes. ${ }^{34-37}$ Biological and histological insights were then sought at the structural and inflammatory levels to further understand this phenomenon.

\section{1 | Structural changes characteristic of FA and NFA}

Increased airway smooth muscle (SM) mass, thickening of the basement membrane, enlarged submucosal glands, and enlargement of the distal alveolar spaces have all been recurrently reported in association with FA/NFA ${ }^{38-42}$ (Table 1 ). SM mass is clearly a major contributor to these episodes and could, via different indirect pathways, be seen as the process underlying AHR. Interestingly, airway SM cells were shown to be hyperplastic without being hyperproliferative, even in FA cases. ${ }^{40,43-45}$ SM hyperplasia might be specific to asthma, but not necessarily fatal episodes. Similarly, the SM layer is currently seen as a contributor to fatal episodes, but not as the ideal culprit. ${ }^{43}$ When considering the course of an episode, fast onset likely relates to non- or poorly inflammatory mechanisms. ${ }^{46,47}$ Examples of the latter may include Zyxin, an actin regulator, which was found to be a SM potential stabilizer that accumulates in the airways of FA. ${ }^{48}$ Additionally, the transcriptomic signature of the SM glucocorticoid receptor response in FA cases was shown to be different from that of non-asthmatics. ${ }^{44}$

Extracellular matrix (ECM) deposition was demonstrated as increased in the airway wall, mostly affecting the outer ring, with higher levels of collagen I, III, fibronectin, proteoglycans (decorin, versican, and lumican), and matrix metalloproteinases (MMPs). ${ }^{49}$ Conversely, observed decreases in elastic fibers were likely involved in loss of elastic recoil, "pseudoemphysematous" changes, and subsequent increases in small airway obstruction. ${ }^{42,50}$ Interestingly, these structural changes frequently reported as "remodeling" have been seen as a Janus paradigm. If the airway lumen is narrowed because the airway wall is thickened because of ECM deposition for example, or edema, a smaller increase in the smooth muscle tone would be sufficient to close the airway. On the other hand, some have suggested that a thickened airway should be stiffer, which may confer protection against excessive smooth muscle constrictionand this may eventually explain why fatal asthma can occur in mild asthmatics and why asthma duration is not a risk factor. ${ }^{51,52}$ Impaired 
TABLE 1 Inflammatory and structural changes found in near-fatal or fatal asthma studies

\begin{tabular}{|c|c|c|c|c|c|}
\hline Compartment & Frequently reported & Sparsely reported & Inflammatory cells & Remarks & Ref \\
\hline Airway lumen & Mucus plugging & Bronchial casts & $\begin{array}{l}\text { Eosinophils } \\
\text { And Neutrophils }\end{array}$ & & {$[53,55,68,85,91]$} \\
\hline $\begin{array}{l}\text { Airway } \\
\quad \text { epithelium }\end{array}$ & Thickened & Desquamated & Eosinophils & $\begin{array}{l}\text { Increased TLR 2, 3, and } 4 \\
\text { Increased TSLP }\end{array}$ & [108] \\
\hline $\begin{array}{l}\text { Submucosal } \\
\text { glands }\end{array}$ & $\begin{array}{l}\text { Enlarged; increase of } \\
\text { myoepithelial cells }\end{array}$ & $\begin{array}{l}\text { Goblet cell } \\
\text { hyperplasia }\end{array}$ & $\begin{array}{l}\text { Eosinophils and neutrophils } \\
\text { Predominent in long courses }\end{array}$ & $\begin{array}{l}\text { No difference in MUC5AC } \\
\text { and MUC5B }\end{array}$ & {$[31,109]$} \\
\hline $\begin{array}{l}\text { Basement } \\
\text { membrane }\end{array}$ & Thickened & & & & \\
\hline $\begin{array}{c}\text { Submucosal } \\
\text { vessels }\end{array}$ & Hypervascularity & & $\begin{array}{l}\text { mast cells, eosinophils, and } \\
\text { neutrophils } \\
\text { lymphoid aggregate }\end{array}$ & & {$[53,74,110]$} \\
\hline $\begin{array}{l}\text { Airway } \\
\text { smooth } \\
\text { muscle }\end{array}$ & Hyperplastic & Hypertrophic & $\begin{array}{l}\text { Mast } \\
\text { Predominent in short course }\end{array}$ & & {$[31,40]$} \\
\hline $\begin{array}{l}\text { Extracellular } \\
\text { matrix }\end{array}$ & $\begin{array}{l}\text { Altered elastic fibers } \\
\text { Increased collagen, } \\
\text { fibonectin, } \\
\text { proteoglycans, and } \\
\text { MMP deposition }\end{array}$ & & $\begin{array}{l}\text { Mast } \\
\text { Eosinophils }\end{array}$ & $\begin{array}{l}\text { Increased FceR1 } \\
\text { expression }\end{array}$ & {$[40,42,111]$} \\
\hline Alveolar level & $\begin{array}{l}\text { Enlargement of the distal } \\
\text { airspaces }\end{array}$ & Disruption & $\begin{array}{l}\text { DC } \\
\text { Eosinophils } \\
\text { Neutrophils }\end{array}$ & & {$[42]$} \\
\hline Lymph nodes & & & Eosinophils & HLA-DR+ & {$[75]$} \\
\hline
\end{tabular}

perception of airflow obstruction is also one of the leading causes of delayed management and a risk for ICU admission and death. However, it was already known in the "before corticosteroid" era that only a fraction of asthmatics were subject to fatal or near-fatal episodes, and therefore, SM and ECM involvement are most often not in themselves sufficient to provoke NF/NFA. In this regard, the final contribution of mucus plugging may then be seen as the critical drop required to make the vase overflow.

Hence, the most striking change described in NFA/FA is the constant description of intense mucus plugging of both the small and large airways ${ }^{39,50,53-57}$ (Figure 1). A decreased density of club cells has also been shown, ${ }^{49}$ supposedly in relation to goblet cell hyperplasia. ${ }^{59}$ Ultimately, authentic and frightening airway casts are removed at autopsy. ${ }^{50,60}$ Additionally, the myoepithelial cells of the submucosal glands were found to be increased. A potential contribution of blood vessels, both bronchial and pulmonary arteries, has also been shown. ${ }^{61}$ A possible worsening of airway narrowing by interstitial emphysema is discussed via a few case reports. ${ }^{62}$

\subsection{Inflammatory changes characteristic of FA and NFA}

Intriguingly, few data recording airway inflammatory patterns at ICU admission exist, despite the availability of new non-invasive sampling techniques (eg, nasal washes) (Table 1). All inflammatory cell types have more-or-less been shown to be increased in FA episodes,

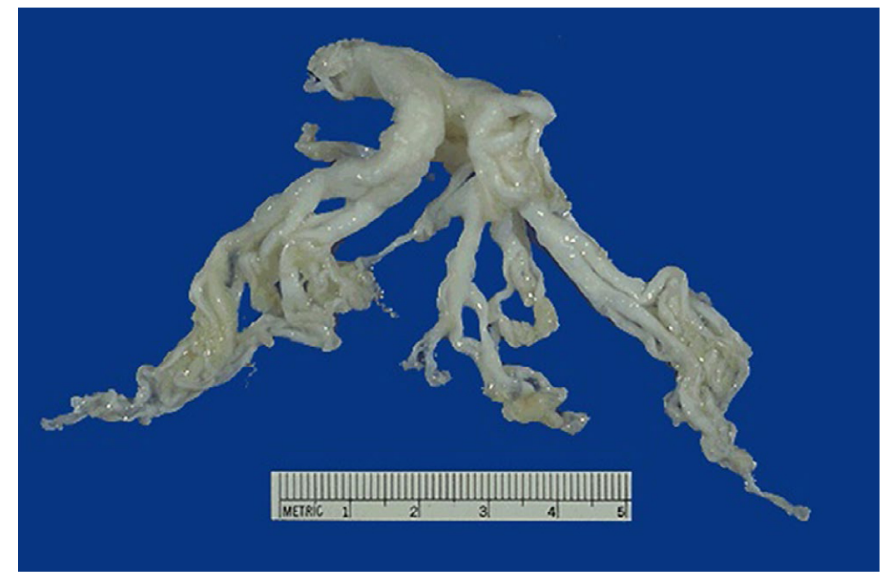

FIGURE 1 Mucus plug shaping a bronchial tree cast coughed by a patient. With permission of Prof Klatt

including B cells, T cells, eosinophils, neutrophils, mast cells, dendritic cells, and invariant natural killer T cells. Variations may be seen according to the onset of the episode: Most of the following findings were found in slow-onset episodes, in contrast with rapid onset (less than $3 \mathrm{~h}$ classically) where inflammatory signals were rarely present. ${ }^{46,47}$ Heterogeneities in the inflammatory patterns seen in asthma at steady state and during an exacerbation, outside the ICU context, are largely known and deciphered thanks to seminal papers. $^{63,64}$ These patterns may change according to the trigger (viral, fungal, bacteria, airborne pollutants, and allergens for example) but 
little is known regarding whether these patterns can change in a given patient (eg, having a T2 exaggerated response after an allergen challenge but T1 in response to a pollutant). Residual exacerbations in IL5-blocked patients may indicate that this scenario may explain why not all patients are super responders. ${ }^{65}$ Asthma exacerbations, including the worst ICU situations requiring ECMO, are largely driven by viral infections, with rhinoviruses being the most commonly found. $3,66,67$

Neutrophils are the predominant inflammatory cells in the airways of FA patients, but this might also be largely attributable to the high doses of corticosteroids these patients receive. ${ }^{68}$ Interestingly, high blood eosinophil counts are associated with more frequent and more severe exacerbations. ${ }^{69,70}$ In this regard, a positive relationship between the blood and airway compartments has been established and clinically used in asthma for initiating biologics, even though many confounders-corticosteroids in first place-demonstrate the limits of this biomarker. ${ }^{71,72}$ Descriptions of relatively similar patterns of inflammation can be found for either the airways, the vessels, and the lymph nodes. ${ }^{32,43,53,69,73-75}$ Mast cell degranulation was found to be related to the time to death but also to mucus plugging. ${ }^{31,76}$ Many mast cell-derived mediators have been shown to be overexpressed in samples assessed at autopsy such as tryptase, chymase, eicosanoids, and others. Not specific to fatal asthma cases, the infiltration of mast cells within the airway smooth muscle bundle was found as a micro-anatomical demonstration of the relationship linking airway hyper-responsiveness (AHR) with inflammation. ${ }^{77-82}$ The complement component receptors $\mathrm{C} 3 \mathrm{aR}$ and $\mathrm{C} 5 \mathrm{aR}$ were found increased in the epithelium and the vessels. ${ }^{83}$ This followed a period where "airway anaphylaxis" was a supposed subphenotype of asthma in the ICU, even though it looks rather complex to address the eventual specificities of the clinical presentations. ${ }^{84}$ Eosinophils are also widely found alongside the entire airway tree in asthma, in FA, and the nose. $^{32}$ Eosinophils are critical contributors to mucus secretion ${ }^{85}$ and rheology, and this can result in clinical consequences measurable at HRCT. ${ }^{55}$ Extracellular eosinophil traps and Charcot-Leyden crystals might be the biological substrate underlying this process. Indeed, anti-galectin10 antibodies may neutralize most of the features classically found during an exacerbation of asthma. ${ }^{86}$ But in the end, mast cells may be the most specific contributor to fatal and near-fatal episodes when compared to exacerbations that are managed in the ward or outside the hospital (but this needs validation). Accordingly, most T2 cytokines are likely involved in the process. Among them, IL4 and IL13 are likely more specific of near-fatal episodes given their contribution to mucus plugging and airway casts, but also the acknowledged importance of mast cells. IL5 and IL8 should be important in granulocyte trafficking, but whether this is of importance at the acutest phase of near-fatal episodes is less clear. Alarmins have never been assessed in this setting. Intuitively, their upstream mechanism of action might be relevant at the earliest phase of these dramatic episodes, as well as their ability to affect both the smooth muscle layer and the submucosal glands. The timing of the T2 cascade is unknown in near-fatal and fatal asthma episodes, and the ideal target can only be suggested by deduction of what is known in other asthma events where immunopathological data are available. At a glance, although heterogeneous inflammatory patterns are characteristic of severe asthma, the most common features found in NFA and FA episodes are evocative of a T2-driven patterns or a mixed T1 and T2 pattern-finally similar to that seen in the ward. ${ }^{87,88}$

Figures 2 and 3 summarize all these findings at the small airway level, highlighting the specificities related to near-fatal asthma.

\section{3 | EPIDEMIOLOGY, NATURAL HISTORY, AND TRAJECTORIES LEADING TO ICU ADMISSION}

Achieving a definite diagnosis of asthma in the ICU is complex, and this may explain why epidemiological data are not as robust as they might be. This is moreover true when patients are old, comorbid, unable to talk, and frequently exhibit overlapping features with COPD in their past history and/or non-CF bronchiectasis (if seen by the angle of HRCT). Epidemiological data are also sparse and heterogeneous among countries. Thanks to the Global Burden of Disease study group, it is known that around 0.40 million people ( 0.36 to 0.44 million) died from asthma in 2015 , a decrease of $26.7 \%(-7.2$ to 43.7$)$ from $1990 .{ }^{89}$ Once in the emergency department, around one half of patients are admitted whereas only $26 \%$ of asthma attacks present "life threatening" features. It is also worth recalling at this time that not all episodes pass through an ED and that some asthma deaths occur outside the hospital (eg, in the street, in jail, and at home). ${ }^{90-93}$ The average length of stay is around 6 days, with huge discrepancies and large ranges depending on the healthcare system, age, and comorbidities. ${ }^{91,94,95}$ Prognosis is dominated by age and comorbidities. $^{93,96}$ The risk of developing ICU-related adverse events such as diabetes, ventilator-associated pneumonia, neuromyopathy, and ventilator-associated barotrauma ultimately leading to hazardous pneumothorax and/or pneumomediastinum are

FIGURE 2 Representative illustrations of a small airway. (A) in mild asthma, important findings are as follows: Eosinophil, Limited mast cell myositis, Activated airway epithelium, No mucus plugging, and Efficient elastic fiber network. (B) during an exacerbation of asthma, consistent findings are as follows: Eosinophils and neutrophils, T cells, Smooth muscle hyperplasia, Hyper-activated airway epithelium and Thickened basement membrane. (C) in a near-fatal or fatal episodes, specific findings are: mucus plug-airway casts, intense mast cell myositis, aggregated T cells, intense outer-wall ECM deposition, disrupted elastic fiber network, intense inner-wall ECM, hypervascularity, perivascular inflammation, and loss of alveolar attachments 

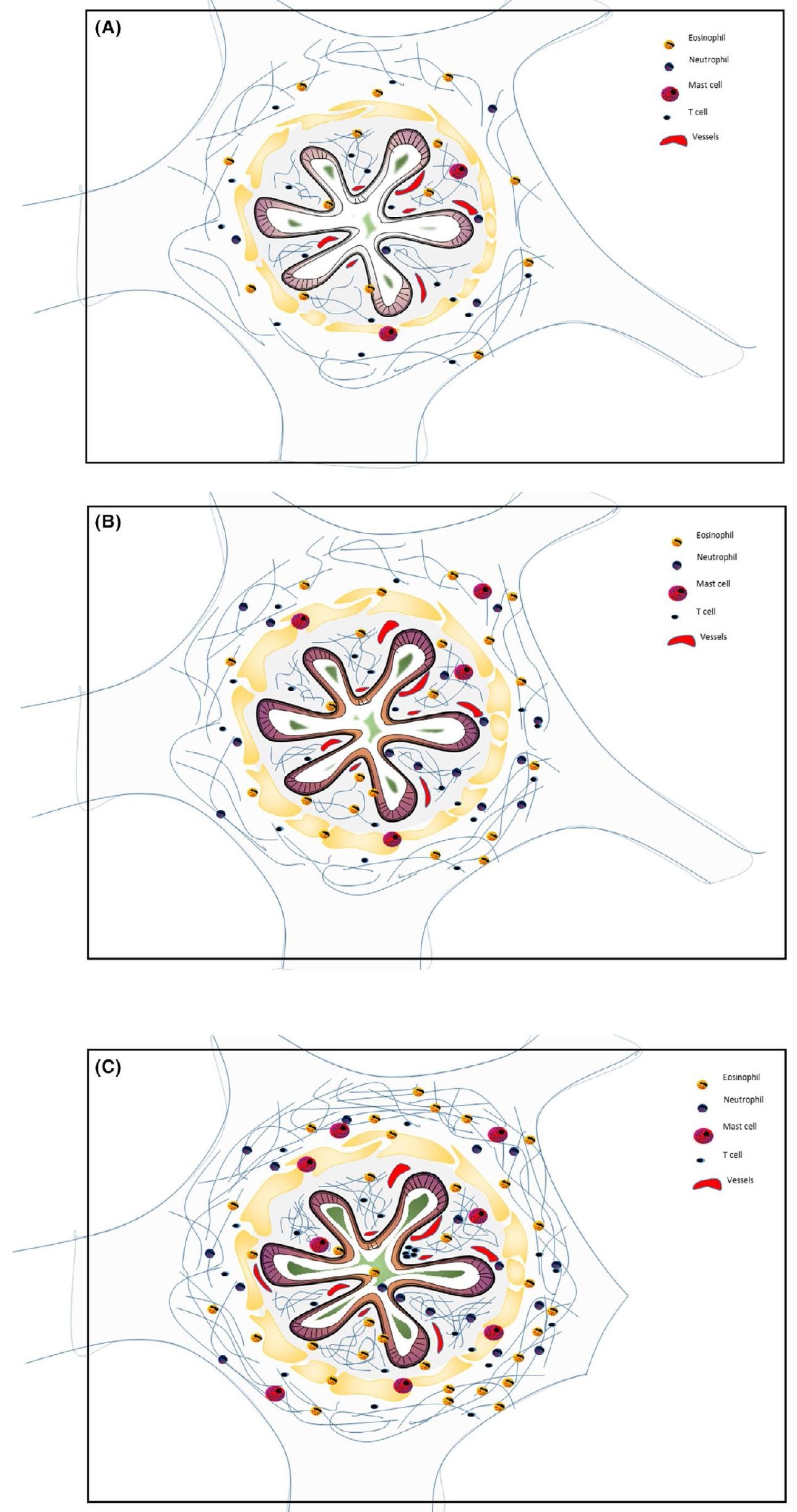
(A)

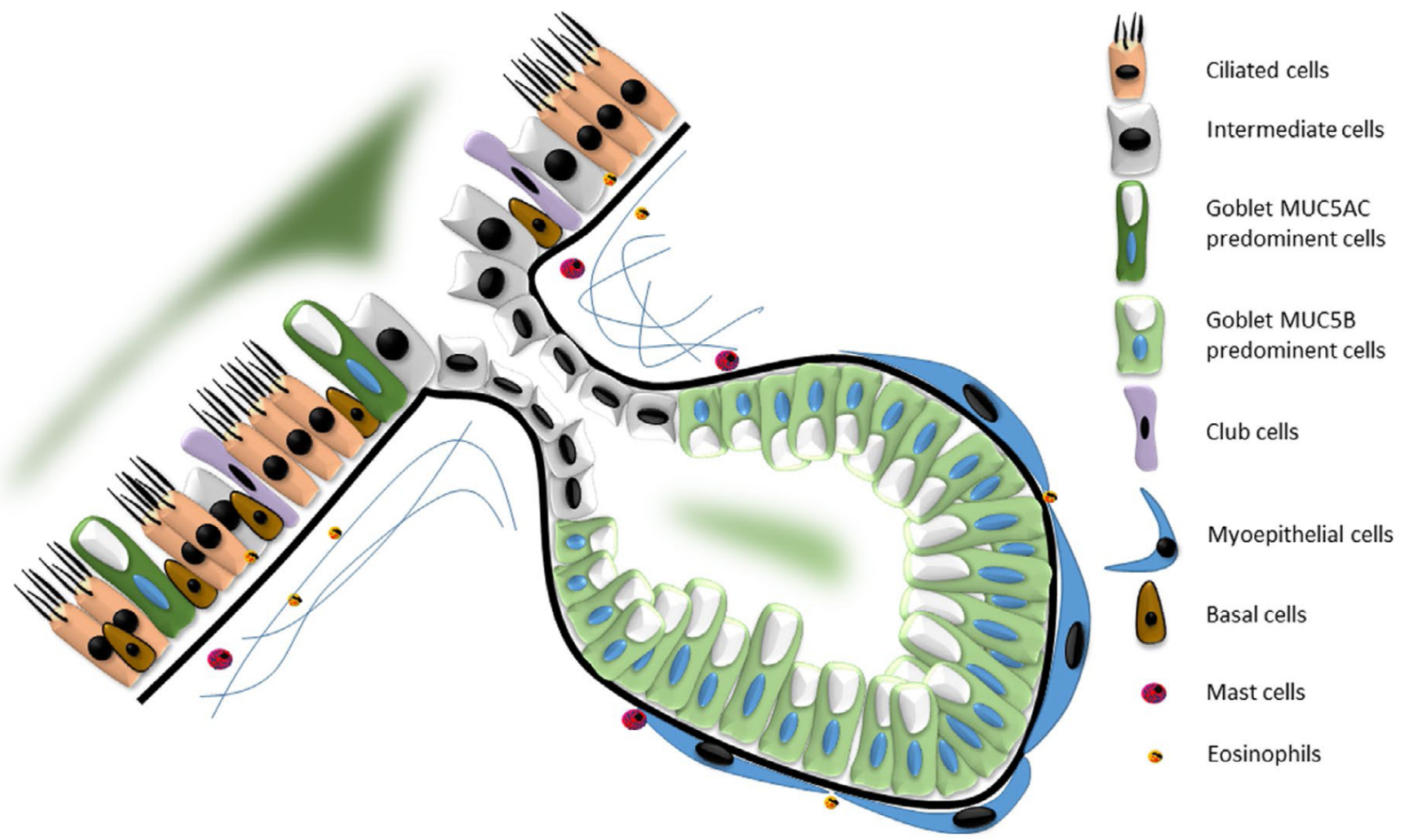

(B)

\section{Near-fatal Asthma} Eosinophilic infiltration Mast cell infiltration Subepithelial gland mast cell Myoepithelial cell hyperplasia Mucus plugging - casts ECM deposition Goblet cell hyperplasia Decreased club cell
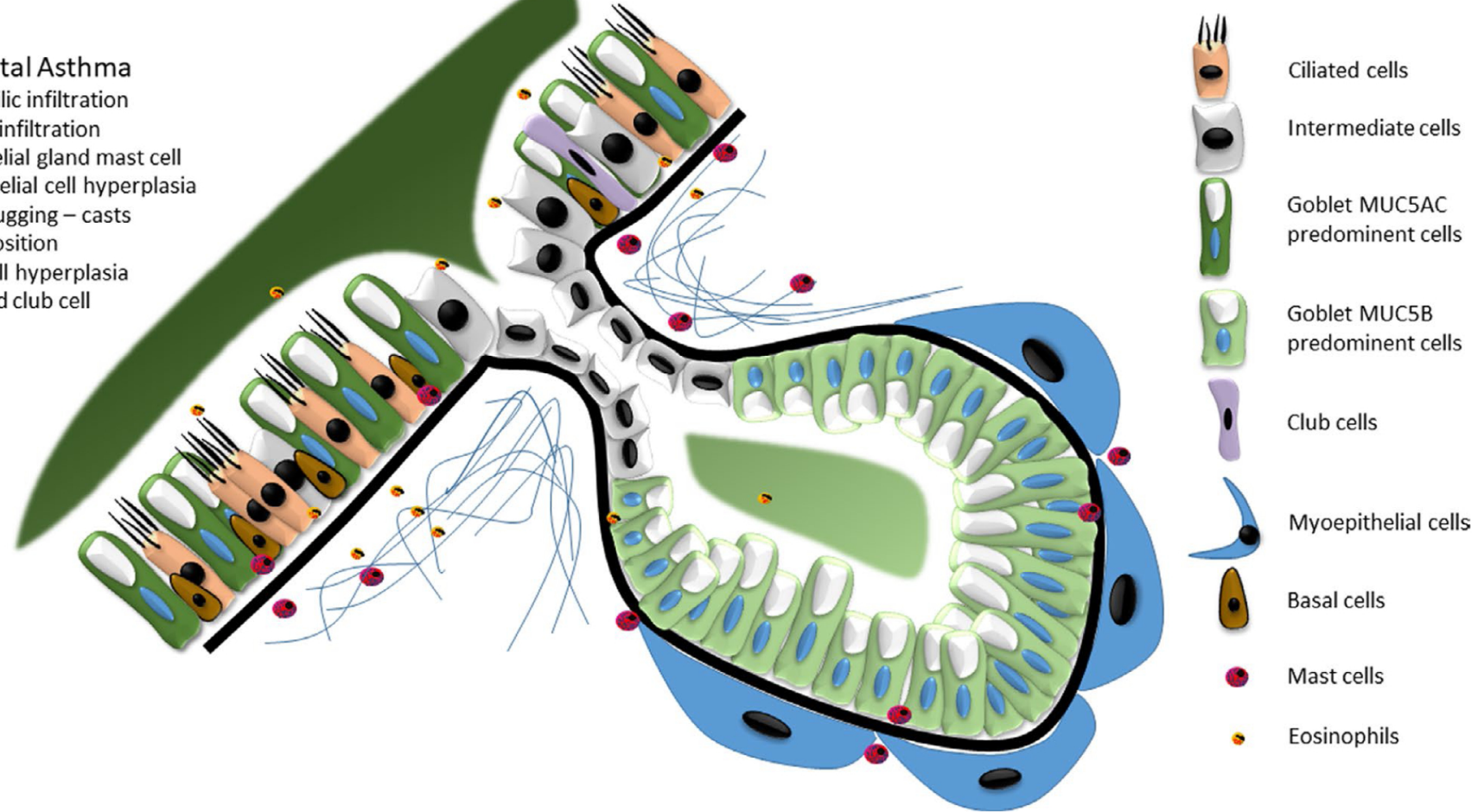

FIGURE 3 Representative illustrations of the small airway epithelium and submucosal glands in (A) mild asthma and (B) near-fatal or fatal asthma with eosinophilic infiltration, mast cell infiltration, subepithelial gland mast cell, myoepithelial cell hyperplasia, mucus plugging-casts, ECM deposition, goblet cell hyperplasia, and decreased club cell density

classic, but relevant rates are poorly reported. ${ }^{92,97-99}$ In-hospital mortality rates range between $1 \%$ and $1.45 \%$ in various studies in the ward, but can reach nearly $10 \%$ in patients intubated in the ICU, ${ }^{96,100,101}$ stressing the importance of developing new therapeutic approaches. In a twenty-year follow-up study of patients with severe asthma, 10 among 52 finally died of a fatal asthma episode despite being optimally managed. ${ }^{7}$

\section{4 | THE CURRENT UNMET NEEDS OF INTENSIVE CARE FOR ASTHMA AND THE OPPORTUNITY TO USE T2 TARGETING BIOLOGICS}

In ICU-admitting asthma, mucus plugging eventually leading to airway casts appears as the most striking barrier to punch through, 


\section{BOX 1 Patient perspectives}

"Better understanding the mechanisms that lead to near fatal and fatal exacerbations in asthma is important. Creating insights that could lead to more effective treatment resulting in fewer fatal attacks would be beneficial to patients. "Better understanding the mechanisms that lead to near fatal and fatal exacerbations in asthma is important. Creating insights that could lead to more effective treatment resulting in fewer fatal attacks would be beneficial to patients.

Survival is important from a patient perspective, but not only survival. Recuperation after a severe, near fatal asthma attack that requires admittance to an ICU is important. Does the treatment used in the ICU to increase survival support recovery? What is the impact of the treatment chosen on the co-morbidities that are an integral part of the patients' burden of disease?

I realize that very often survival is seen as the most important, the one and only goal, and that is understandable. It would however be great if survival could be combined with a positive outcome on recuperation and quality of life for the patient. The impact on the patient's lungs, asthma, comorbidities and other bodily functions of a very severe asthma attack should be included in the considerations of what treatments are preferred for that patient. If we can combine survival with as little harm as possible, that would be the best outcome.

What is also often lacking from a patient perspective after an ICU stay is tailor-made counselling and support for the patient and his or her carers during the recuperation in hospital and at home. This might also decrease the feelings of uncertainty and fear in both patients and carers and facilitate recovery."

literally as well as figuratively. The complexity of finding effective mechanical ventilation settings is consistently reported, given the high regimen of pressure aiming at preventing barotrauma and subsequent complications. Onset of action of currently available drugs (such as bronchodilators and systemic steroids) is clearly a current limitation, especially in very rapidly progressing episodes. The current use of helium-oxygen, magnesium sulfate, and others suggest that more potent bronchodilators are required. Indeed, this may indicate the need for blocking mucus production, which at least depends on eosinophilic inflammation, mast cell degranulation, and IL13. Accordingly, all the currently available biologics, if they act fast enough, are likely to provide benefits to NFA management. The main aim would be to reduce the rates of ICU admission and intubation, and accelerate recovery from episodes that may have progressed with such rapidity as to preclude starting the

\section{BOX 2 Main needs in ICU-admitted asthma}

Mechanistic

How can airway mucus plugging be prevented?

Does a NFA episode indicate T2 inflammation per se?

Clinical

Prevent intubation

Determine optimal ventilator settings when required Identify when ECMO and/or ECCOR are indicated

Decrease in-hospital mortality

Reduce massive OCS and SABA exposure and subsequent side effects

Should steroid-naïve patients be initiated with a biological?

Reduce length of stay

Reduce ICU-related adverse events (neuromyopathy, ven-

tilator-acquired pneumonia, etc)

Prevent readmission

Reduce overall psychological distress related to ICU admission-fear of readmission

drug before intubation was required in order to prevent ICU-related complications.

Given the high dose of systemic steroids administered, side effects (and in particular the risk of ventilator-acquired pneumonia) are important with potentially poor outcomes. Neuromuscular blockades associated with sedation and steroids can lead to ICUassociated neuromyopathy, a great cause of concern given the subsequent massive burden.

Psychological distress and anxiety related to ICU admissions, asphyxia, and relapse have gained in awareness, but are not always well taken into account clinically. Finally, it is worth remembering that most patients who have been admitted to an ICU are excluded from most clinical trials and are thus under-represented in research. A synthesis of the main clinical needs is proposed BOX 2.

\section{5 | AVAILABLE T2-TARGETING BIOLOGICS IN SEVERE ASTHMA AND THEIR POTENTIAL USEFULNESS IN THE ICU}

Table 2 summarizes available pharmacological and clinical data. Only one study was performed in an emergency department, but with the aim of preventing readmission successfully reached. ${ }^{102}$ Intuitively, and because IL5 targeted-treated patients present less frequent but also less severe exacerbations than those receiving placebo, both mepolizumab and benralizumab have been successfully used in some cases. ${ }^{65,103-106}$ Conversely, given their respective T2 targets, there is a strong rational for testing other biologics such as reslizumab obviously, but also dupilumab, in the 
TAB LE 2 Currently available biologics in severe asthma. Pharmacological characteristics, established benefits, and possible benefits in the ICU

\begin{tabular}{|c|c|c|c|c|c|c|c|c|}
\hline & Route & Pharmacokinetic & Bio-disponilibity & Half life & Elimination & $\begin{array}{l}\text { Current } \\
\text { posology }\end{array}$ & $\begin{array}{l}\text { Mechanism } \\
\text { of action }\end{array}$ & $\begin{array}{l}\text { OCS } \\
\text { sparing }\end{array}$ \\
\hline Omalizumab & SC & $\begin{array}{l}\text { IgE binding: Peak at } \\
\text { day } 3 \text { (urticaria), } \\
\text { detectable after } \\
\text { 1h }\end{array}$ & $68 \%$ & 6-8 days & $\begin{array}{l}\text { IgG and IgE } \\
\text { complexes } \\
\text { (reticulo- } \\
\text { endothelial } \\
\text { system- } \\
\text { liver) }\end{array}$ & Q2 - Q4 & Anti lgE & $?$ \\
\hline Mepolizumab & SC & Peak 4-8d & $64 \%-80 \%$ & 16-22 days & $\begin{array}{l}\text { Proteolytic } \\
\text { enzymes }\end{array}$ & Q4 & Anti IL5 & $-50 \%$ \\
\hline Benralizumab & $\mathrm{SC}$ & $\begin{array}{l}\text { Eosinophilic } \\
\text { depletion at } 24 \mathrm{~h}\end{array}$ & $59 \%$ & 15.5 days & $\begin{array}{r}\text { Proteolytic } \\
\text { enzymes }\end{array}$ & Q8 & Anti IL5R & $-75 \%$ \\
\hline Reslizumab & IV & Immediate & $100 \%$ & 24 days & $\begin{array}{l}\text { Proteolytic } \\
\text { enzymes }\end{array}$ & Q4 & Anti IL5 & ? \\
\hline Dupilumab & $\mathrm{SC}$ & Tmax 3-7 days & $61 \%-64 \%$ & $\begin{array}{l}\text { Non-linear } \\
\text { 9-11 weeks }\end{array}$ & $\begin{array}{l}\text { Proteolytic } \\
\text { enzymes }\end{array}$ & Q2 & Anti IL4 IL13 & $-70 \%$ \\
\hline
\end{tabular}

Abbreviations: NP, nasal polyps; HES, hypereosinophilic syndrome; EEo, eosinophilic oesophagitis; EGPA, eosinophilic granulomatosis with polyangeitis; $A D$, atopic dermatitis; $A H R$, airway hyper-responsiveness.

ICU. Which of the available mAbs would most likely be efficient in the ICU? This question must be carefully considered not only in terms of mechanisms, but also pharmacokinetics (PK). The usual criteria used for assessing small molecules are not transposable to mAbs. This is because the mechanisms of binding, internalization, and diffusion are complex, and the resulting plethora of variables can preclude efficient PK models. According to available data (summarized in Table 2), the immediate availability conferred by intravenous Reslizumab makes it one likely candidate. However, the superiority of the latter over a subcutaneous administration is not obvious and should not be assumed based on this unique characteristic. As concerns benralizumab, eosinophil depletion starts as early as $24 \mathrm{hr}$ after the first administration, making this drug a second likely candidate-and available case reports support this point. These examples demonstrate how different aspects of pharmacological assessment may come into play. Current data describing mechanisms of action and immediate clinical and biomarker responses are limited and a crucial area of research. For example, very rapid improvements were reported with dupilumab in the SINUS studies ${ }^{107}$ (around $48 \mathrm{~h}$ for smell recovery in some patients) whereas the currently available data do not necessarily support such rapid improvement given the need for 3-7 days to reach the Tmax. Finally, little is known about the immediate kinetics of IL4 versus IL13 blockades, which both target the alpha subunit of the IL4-receptor. However, that PK difference may considerably affect efficiency in the ICU.

\section{6 | CONCLUSION}

There is substantial room for improvement in managing asthma in the ICU. Despite recent improvements in managing severe asthma, asthma in the ICU is still a cause for concern. Targeting T2-related features characteristic of near-fatal pathology, such as mucus plugging, smooth muscle constriction, and mast cell degranulation, may help address this issue.

\section{CONFLICT OF INTEREST}

None of the authors report interests related to the present work.

Dr Arnaud Bourdin reports industry-sponsored grants from AstraZeneca-Medlmmune, Boehringer-Ingelheim, Cephalon/ Teva, GlaxoSmithKline, Novartis, Sanofi-Regeneron; consultancies for AstraZeneca-Medlmmune, Boehringer-Ingelheim, GlaxoSmithKline, Novartis, Regeneron-Sanofi, Med-in-Cell, Actelion, Merck, Roche, Chiesi; investigator/Co-investigator activities for trials promoted by AstraZeneca-Medlmmune, BoehringerIngelheim, GlaxoSmithKline, Novartis, Regeneron-Sanofi, Chiesi, Actelion, Merck, Roche, Vertex, Galapagos; no personal financial support from a non-commercial source; no personal relationships with tobacco industry entities; no off-label disclosures. Dr Charriot, Dr Boissin, Dr Ahmed, Mr De Sevin, Dr Volpato, Dr Gras, and Dr Isabelle Vachier have no conflict of interest to declare. Dr Carey Suehs reports one grant from Astra Zeneca. Dr Laurie PAHUS reports consultancies for Astra Zeneca and Chiesi pharmaceuticals. 


\begin{tabular}{llllll}
$\begin{array}{l}\text { Exacerbation } \\
\text { rate }\end{array}$ & $\begin{array}{l}\text { FEV1 } \\
\text { improvement }\end{array}$ & $\begin{array}{l}\text { Comorbidities } \\
\text { covered }\end{array}$ & $\begin{array}{l}\text { Known effect } \\
\text { in ICU }\end{array}$ & $\begin{array}{l}\text { Likelihood of acute } \\
\text { effect in ICU }\end{array}$ & Side effects \\
\hline$-50 \%$ & Likely & Urticaria, NP & None & IgE binding is present & Very rare \\
in NFA. Rapid lgE & anaphylaxis \\
& & & neutralization. May & target mast cells.
\end{tabular}

\begin{tabular}{|c|c|c|c|c|c|c|}
\hline$-60 \%$ & $100 \mathrm{ml}$ & $\begin{array}{c}\text { NP, HES, EEo, } \\
\text { EGPA }\end{array}$ & None & $\begin{array}{l}\text { Eosinophils are highly } \\
\text { present and may } \\
\text { participate in both } \\
\text { mucus and AHR }\end{array}$ & $\begin{array}{l}\text { Post-marketing } \\
\text { indicates } \\
\text { possible } \\
\text { very rare } \\
\text { anaphylaxis }\end{array}$ & {$[21]$} \\
\hline$-60 \%$ & $100 \mathrm{ml}$ & NP, HES, EGPA & $\begin{array}{l}\text { Prevention of } \\
\text { readmission } \\
\text { One case report }\end{array}$ & $\begin{array}{l}\text { Eosinophils are highly } \\
\text { present and may } \\
\text { participate in both } \\
\text { mucus and AHR }\end{array}$ & - & {$[22,105$} \\
\hline$-60 \%$ & $100 \mathrm{ml}$ & & None & $\begin{array}{l}\text { Eosinophils are highly } \\
\text { present and may } \\
\text { participate in both } \\
\text { mucus and AHR }\end{array}$ & $\begin{array}{l}\text { Very rare } \\
\text { anaphylaxis }\end{array}$ & {$[25]$} \\
\hline$-70 \%$ & $200 \mathrm{ml}$ & $A D, N P$ & None & $\begin{array}{l}\text { Mast cells, mucus, and } \\
\text { smooth muscles are } \\
\text { potentially targeted } \\
\text { by IL4 and IL13. }\end{array}$ & $\begin{array}{l}\text { Possible transient } \\
\text { blood } \\
\text { eosinophilia }\end{array}$ & {$[23]$} \\
\hline
\end{tabular}

Dr Laurence Halimi reports industry-sponsored grants and lecturer activities for GlaxoSmithKline, Actelion, and Novartis. D. Hamerlijnck is a patient expert for European Federation of Allergy and Airways (EFA) and European Lung Foundation (ELF), a patient independent advisor to Novartis and Chiesi on patient involvement; patient co-chair of the ERS Severe Heterogeneous Asthma Registry, Patient-centred CRC, and a GINA advocate; Dr Pascal Chanez, as an advisory board member, consultant, or lecturer, has previously received honoraria or grants from Boehringer Ingeheim, Almirall, Centocor, GSK, MSD, Astra Zeneca, Novartis, Teva, Chiesi, Shering Plough, and Aix Marseille University.

\section{REFERENCES}

1. Ernst $P$, Spitzer WO, Suissa $S$, et al. Risk of fatal and near-fatal asthma in relation to inhaled corticosteroid use. JAMA. 1992;268:3462-3464.

2. Suissa S, Ernst P, Benayoun S, et al. Low-dose inhaled corticosteroids and the prevention of death from asthma. NEngl J Med. 2000;343:332336. https://doi.org/10.1056/NEJM200008033430504

3. Bourdin A, Bjermer L, Brightling C, et al. ERS/EAACl Statement on severe exacerbations in asthma in adult: facts, priorities and key research questions. Eur Respir J. 2019;54(3). https://doi. org/10.1183/13993003.00900-2019

4. Fuhlbrigge A, Peden D, Apter AJ, et al. Asthma outcomes: exacerbations. J Allergy Clin Immunol. 2012;129:S34-S48. https://doi. org/10.1016/j.jaci.2011.12.983
5. Reddel HK, FitzGerald JM, Bateman ED, et al. GINA 2019: a fundamental change in asthma management: treatment of asthma with short-acting bronchodilators alone is no longer recommended for adults and adolescents. Eur Respir J. 2019;53(6):1901046. https:// doi.org/10.1183/13993003.01046-2019

6. Price DB, Trudo F, Voorham J, et al. Adverse outcomes from initiation of systemic corticosteroids for asthma: long-term observational study. J Asthma Allergy. 2018;11:193-204. https://doi. org/10.2147/JAA.S176026

7. Bourdin A, Molinari N, Vachier I, et al. Mortality: a neglected outcome in OCS-treated severe asthma. Eur Respir J. 2017;50(5):1701486. https://doi.org/10.1183/13993003.01486-2 017

8. Sweeney J, Brightling CE, Menzies-Gow A, et al. Clinical management and outcome of refractory asthma in the UK from the British Thoracic Society Difficult Asthma Registry. Thorax. 2012;67:754-756. https://doi.org/10.1136/thora xjnl-2012-201869

9. Al-Dorzi HM, Al-Shammary HA, Al-Shareef SY, et al. Risk factors, management and outcomes of patients admitted with near fatal asthma to a tertiary care hospital in Riyadh. Ann Thorac Med. 2014;9:33-38. https://doi.org/10.4103/1817-1737.124441

10. Alvarez GG, Schulzer M, Jung D, Fitzgerald JM. A systematic review of risk factors associated with near-fatal and fatal asthma. Can Respir J. 2005;12:265-270.

11. Gelb AF, Schein A, Nussbaum E, et al. Risk factors for near-fatal asthma. Chest. 2004;126:1138-1146. https://doi.org/10.1378/ chest.126.4.1138

12. Turner $M$, Noertjojo $K$, Vedal $S$, et al. Risk factors for near-fatal asthma. A case-control study in hospitalized patients with asthma. Am J Respir Crit Care Med. 1998;157:1804-1809. https://doi. org/10.1164/ajrccm.157.6.9708092 
13. Abramson M, Bailey $M$, Couper $F$, et al. Are asthma medications and management related to deaths from asthma? Am J Respir Crit Care Med. 2001;163:12-18. https://doi.org/10.1164/ ajrccm.163.1.9910042

14. Beasley R. A historical perspective of the New Zealand asthma mortality epidemics. J Allergy Clin Immunol. 2006;117:225-228. https://doi.org/10.1016/j.jaci.2005.10.029

15. Pendergraft TB, Stanford RH, Beasley R, et al. Rates and characteristics of intensive care unit admissions and intubations among asthma-related hospitalizations. Ann Allergy Asthma Immunol. 2004;93:29-35. https://doi.org/10.1016/S1081-1206(10)61444-5

16. Doshi V, Shenoy S, Ganesh A, et al. Profile of acute asthma exacerbation in drug users. Am J Ther. 2017;24:e39-e43. https://doi. org/10.1097/MJT.0000000000000118

17. Nair P, Wenzel S, Rabe KF, et al. Oral glucocorticoid-sparing effect of benralizumab in severe asthma. N Engl J Med. 2017;376:24482458. https://doi.org/10.1056/NEJMoa1703501

18. Bel EH, Wenzel SE, Thompson PJ, et al. Oral glucocorticoid-sparing effect of mepolizumab in eosinophilic asthma. N Engl J Med. 2014;371:1189-1197. https://doi.org/10.1056/NEJMoa1403291

19. Rabe KF, Nair P, Brusselle G, et al. Efficacy and safety of dupilumab in glucocorticoid-dependent severe asthma. N Engl J Med. 2018;378:2475-2485. https://doi.org/10.1056/NEJMoa1804093

20. Wu W, Bang S, Bleecker ER, et al. Multiview cluster analysis identifies variable corticosteroid response phenotypes in severe asthma. Am J Respir Crit Care Med. 2019;199(11):1358-1367. https://doi. org/10.1164/rccm.201808-15430C

21. GSK NUCALA. https://www.accessdata.fda.gov/drugsatfda_ docs/label/2019/761122s000lbl.pdf. Accessed 2 Apr 2020.

22. Astra Zeneca FASENRA. https://www.accessdata.fda.gov/drugs atfda_docs/label/2017/761070s000lbl.pdf. Accessed 2 Apr 2020.

23. SANOFI Dupixent. https://www.accessdata.fda.gov/drugsatfda docs/label/2019/761055s014lbl.pdf. Accessed 2 Apr 2020.

24. Novartis xolair_prescribing.pdf. https://www.gene.com/downl oad/pdf/xolair_prescribing.pdf. Accessed 2 Apr 2020.

25. TEVA CINQAERO. https://www.accessdata.fda.gov/drugsatfda_ docs/label/2016/761033lbl.pdf. Accessed 2 Apr 2020

26. Castro M, Corren J, Pavord ID, et al. Dupilumab efficacy and safety in moderate-to-severe uncontrolled asthma. N Engl J Med. 2018;378:2486-2496. https://doi.org/10.1056/NEJMoa1804092

27. Bleecker ER, FitzGerald JM, Chanez P, et al. Efficacy and safety of benralizumab for patients with severe asthma uncontrolled with high-dosage inhaled corticosteroids and long-acting $\beta 2$-agonists (SIROCCO): a randomised, multicentre, placebo-controlled phase 3 trial. Lancet. 2016;388:2115-2127. https://doi.org/10.1016/ S0140-6736(16)31324-1

28. Ortega HG, Liu MC, Pavord ID, et al. Mepolizumab treatment in patients with severe eosinophilic asthma. N Engl J Med. 2014;371:1198-1207. https://doi.org/10.1056/NEJMoa1403290

29. Castro M, Zangrilli J, Wechsler ME, et al. Reslizumab for inadequately controlled asthma with elevated blood eosinophil counts: results from two multicentre, parallel, double-blind, randomised, placebo-controlled, phase 3 trials. Lancet Respir Med. 2015;3:355366. https://doi.org/10.1016/S2213-2600(15)00042-9

30. Cabon Y, Molinari N, Marin G, et al. Comparison of anti-interleukin-5 therapies in patients with severe asthma: global and indirect meta-analyses of randomized placebo-controlled trials. Clin Exp Allergy. 2017;47:129-138. https://doi.org/10.1111/cea.12853

31. James AL, Elliot JG, Abramson MJ, Walters EH. Time to death, airway wall inflammation and remodelling in fatal asthma. Eur Respir J. 2005;26:429-434. https://doi.org/10.1183/09031936.05.00146 404

32. de Magalhaes Simoes $S$, dos Santos MA, da Silva Oliveira M, et al. Inflammatory cell mapping of the respiratory tract in fatal asthma. Clin Exp Allergy. 2005;35:602-611. https://doi. org/10.1111/j.1365-2222.2005.02235.x
33. Venegas JG, Winkler T, Musch G, et al. Self-organized patchiness in asthma as a prelude to catastrophic shifts. Nature. 2005;434:777782. https://doi.org/10.1038/nature03490

34. Wagner EM, Bleecker ER, Permutt S, Liu MC. Direct assessment of small airways reactivity in human subjects. Am J Respir Crit Care Med. 1998;157:447-452.

35. Wagner EM, Liu MC, Weinmann GG, et al. Peripheral lung resistance in normal and asthmatic subjects. Am Rev Respir Dis. 1990;141:584-588. https://doi.org/10.1164/ajrccm/141.3.584

36. King GG, Carroll JD, Müller NL, et al. Heterogeneity of narrowing in normal and asthmatic airways measured by HRCT. Eur Respir J. 2004;24:211-218.

37. Ohrui T, Sekizawa K, Yanai M, et al. Partitioning of pulmonary responses to inhaled methacholine in subjects with asymptomatic asthma. Am Rev Respir Dis. 1992;146:1501-1505. https://doi. org/10.1164/ajrccm/146.6.1501

38. Carroll N, Elliot J, Morton A, James A. The structure of large and small airways in nonfatal and fatal asthma. Am Rev Respir Dis. 1993;147:405-410. https://doi.org/10.1164/ajrccm/147.2.405

39. Green FHY, Williams DJ, James A, et al. Increased myoepithelial cells of bronchial submucosal glands in fatal asthma. Thorax. 2010;65:32-38. https://doi.org/10.1136/thx.2008.111435

40. James AL, Elliot JG, Jones RL, et al. Airway smooth muscle hypertrophy and hyperplasia in asthma. Am J Respir Crit Care Med. 2012;185:1058-1064. https://doi.org/10.1164/rccm.20111 $0-18490 \mathrm{C}$

41. Gelb AF, Yamamoto A, Mauad T, et al. Unsuspected mild emphysema in nonsmoking patients with chronic asthma with persistent airway obstruction. J Allergy Clin Immunol. 2014;133:263-265.e3. https://doi.org/10.1016/j.jaci.2013.09.045

42. Mauad T, Silva LFF, Santos MA, et al. Abnormal alveolar attachments with decreased elastic fiber content in distal lung in fatal asthma. Am J Respir Crit Care Med. 2004;170:857-862. https://doi. org/10.1164/rccm.200403-305OC

43. James AL, Noble PB, Drew S-A, et al. Airway smooth muscle proliferation and inflammation in asthma. J Appl Physiol. 2018;125:1090-1096. https://doi.org/10.1152/japplphysiol.003 42.2018

44. Kan M, Koziol-White C, Shumyatcher M, et al. Airway smooth muscle-specific transcriptomic signatures of glucocorticoid exposure. Am J Respir Cell Mol Biol. 2019;61:110-120. https://doi. org/10.1165/rcmb.2018-03850C

45. Dolhnikoff $M$, da Silva LFF, de Araujo BB, et al. The outer wall of small airways is a major site of remodeling in fatal asthma. $J$ Allergy Clin Immunol. 2009;123(5):1090-1097.e1. https://doi. org/10.1016/j.jaci.2009.02.032

46. Serrano-Pariente J, Plaza V. Near-fatal asthma: a heterogeneous clinical entity. Curr Opin Allergy Clin Immunol. 2017;17:28-35. https://doi.org/10.1097/ACI.0000000000000333

47. Hyzy RC, Travis WD, Hanna E, et al. Slow-onset asthma deaths have more eosinophils and health care utilization than rapid-onset deaths. Respir Med. 2008;102:1819-1826. https://doi. org/10.1016/j.rmed.2008.06.011

48. Rosner SR, Pascoe CD, Blankman E, et al. The actin regulator zyxin reinforces airway smooth muscle and accumulates in airways of fatal asthmatics. PLoS One. 2017;12:e0171728. https://doi. org/10.1371/journal.pone.0171728

49. de Medeiros Matsushita M, da Silva LFF, dos Santos MA, et al. Airway proteoglycans are differentially altered in fatal asthma. $J$ Pathol. 2005;207:102-110. https://doi.org/10.1002/path.1818

50. Carroll N, Perry S, Karkhanis A, et al. The airway longitudinal elastic fiber network and mucosal folding in patients with asthma. Am J Respir Crit Care Med. 2000;161:244-248. https://doi.org/10.1164/ ajrccm.161.1.9805005

51. Milanese M, Crimi E, Scordamaglia A, et al. On the functional consequences of bronchial basement membrane thickening. $J$ 
Appl Physiol. 2001;91:1035-1040. https://doi.org/10.1152/jappl. 2001.91.3.1035

52. McParland BE, Macklem PT, Paré PD. Airway wall remodeling: friend or foe? J Appl Physiol. 2003;95:426-434. https://doi. org/10.1152/japplphysiol.00159.2003

53. Carroll NG, Mutavdzic S, James AL. Increased mast cells and neutrophils in submucosal mucous glands and mucus plugging in patients with asthma. Thorax. 2002;57:677-682.

54. Kuyper LM, Paré PD, Hogg JC, et al. Characterization of airway plugging in fatal asthma. Am J Med. 2003;115:6-11. https://doi. org/10.1016/s0002-9343(03)00241-9

55. Dunican EM, Elicker BM, Gierada DS, et al. Mucus plugs in patients with asthma linked to eosinophilia and airflow obstruction. J Clin Invest. 2018;128:997-1009. https://doi.org/10.1172/JC195693

56. Chen FH, Samson KT, Miura K, et al. Airway remodeling: a comparison between fatal and nonfatal asthma. J Asthma. 2004;41:631638. https://doi.org/10.1081/jas-200026405

57. Benatar SR. Fatal asthma. N Engl J Med. 1986;314:423-429. https:// doi.org/10.1056/NEJM198602133140706

58. Shijubo $\mathrm{N}$, Itoh $\mathrm{Y}$, Yamaguchi $\mathrm{T}$, et al. Clara cell protein-positive epithelial cells are reduced in small airways of asthmatics. Am J Respir Crit Care Med. 1999;160:930-933. https://doi.org/10.1164/ ajrccm.160.3.9803113

59. Ruiz García S, Deprez M, Lebrigand K, et al. Novel dynamics of human mucociliary differentiation revealed by single-cell RNA sequencing of nasal epithelial cultures. Development. 2019;146(20):dev177428. https://doi.org/10.1242/dev.177428

60. Rubin BK, Priftis KN, Schmidt HJ, Henke MO. Secretory hyperresponsiveness and pulmonary mucus hypersecretion. Chest 2014;146:496-507. https://doi.org/10.1378/chest.13-2609

61. Rossi RC, Anonni R, Ferreira DS, et al. Structural alterations and markers of endothelial activation in pulmonary and bronchial arteries in fatal asthma. Allergy Asthma Clin Immunol. 2019;15:50. https://doi.org/10.1186/s13223-019-0363-0

62. Mauad T, Nascimento FBPd, Dolhnikoff M, et al. Pulmonary interstitial emphysema in fatal asthma: case report and histopathological review. BMC Pulm Med. 2018;18:50. https://doi.org/10.1186/ s12890-018-0615-7

63. Fraenkel DJ, Bardin PG, Sanderson G, et al. Lower airways inflammation during rhinovirus colds in normal and in asthmatic subjects. Am J Respir Crit Care Med. 1995;151:879-886. https://doi. org/10.1164/ajrccm/151.3_Pt_1.879

64. Wang F, He XY, Baines KJ, et al. Different inflammatory phenotypes in adults and children with acute asthma. Eur Respir J. 2011;38:567-574. https://doi.org/10.1183/09031936.00170110

65. Poznanski SM, Mukherjee M, Zhao N, et al. Asthma exacerbations on benralizumab are largely non-eosinophilic. Allergy. 2021; 76(1):375-379. https://doi.org/10.1111/all.14514

66. Patel S, Shah NM, Malhotra AM, et al. Inflammatory and microbiological associations with near-fatal asthma requiring extracorporeal membrane oxygenation. ERJ Open Res. 2020;6(1):00267-2019. https://doi.org/10.1183/23120541.00267-2019

67. Corne JM, Marshall C, Smith S, et al. Frequency, severity, and duration of rhinovirus infections in asthmatic and non-asthmatic individuals: a longitudinal cohort study. Lancet. 2002;359(1):831834. https://doi.org/10.1016/S0140-6736(02)07953-9

68. Lamblin C, Gosset P, Tillie-leblond I, et al. Bronchial neutrophilia in patients with noninfectious status asthmaticus. Am J Respir Crit Care Med. 1998;157:394-402. https://doi.org/10.1164/ajrccm. 157.2.97-02099

69. Yii ACA, Tay T-R, Puah SH, et al. Blood eosinophil count correlates with severity of respiratory failure in life-threatening asthma and predicts risk of subsequent exacerbations. Clin Exp Allergy. 2019;49(12):1578-1586. https://doi.org/10.1111/cea.13465
70. Price DB, Rigazio A, Campbell JD, et al. Blood eosinophil count and prospective annual asthma disease burden: a UK cohort study. Lancet Respir Med. 2015;3:849-858. https://doi.org/10.1016/ S2213-2600(15)00367-7

71. Westerhof GA, Korevaar DA, Amelink M, et al. Biomarkers to identify sputum eosinophilia in different adult asthma phenotypes. Eur Respir J. 2015;46:688-696. https://doi.org/10.1183/09031 936.00012415

72. Mukherjee M, Nair P. Blood or sputum eosinophils to guide asthma therapy? Lancet Respir Med. 2015;3:824-825. https://doi. org/10.1016/S2213-2600(15)00419-1

73. Elliot JG, Noble PB, Mauad T, et al. Inflammation-dependent and independent airway remodelling in asthma. Respirology. 2018;23:1138-1145. https://doi.org/10.1111/resp.13360

74. Elliot JG, Jensen CM, Mutavdzic S, et al. Aggregations of lymphoid cells in the airways of nonsmokers, smokers, and subjects with asthma. Am J Respir Crit Care Med. 2004;169:712-718. https://doi. org/10.1164/rccm.200308-11670C

75. Cagnoni EF, Ferreira DS, Ferraz da Silva LF, et al. Bronchopulmonary lymph nodes and large airway cell trafficking in patients with fatal asthma. J Allergy Clin Immunol. 2015;135(5):1352-1357.e9. https:// doi.org/10.1016/j.jaci.2014.08.021

76. Elliot JG, Abramson MJ, Drummer $\mathrm{OH}$, et al. Time to death and mast cell degranulation in fatal asthma. Respirology. 2009;14:808813. https://doi.org/10.1111/j.1440-1843.2009.01551.x

77. Berger P, Girodet P-O, Begueret H, et al. Tryptase-stimulated human airway smooth muscle cells induce cytokine synthesis and mast cell chemotaxis. FASEB J. 2003;17:2139-2141. https://doi. org/10.1096/fj.03-0041fje

78. El-Shazly A, Berger P, Girodet P-O, et al. Fraktalkine produced by airway smooth muscle cells contributes to mast cell recruitment in asthma. J Immunol. 2006;176:1860-1868. https://doi. org/10.4049/jimmunol.176.3.1860

79. Girodet P-O, Ozier A, Trian T, et al. Mast cell adhesion to bronchial smooth muscle in asthma specifically depends on CD51 and CD44 variant 6. Allergy. 2010;65:1004-1012. https://doi. org/10.1111/j.1398-9995.2009.02308.x

80. Hollins F, Kaur D, Yang W, et al. Human airway smooth muscle promotes human lung mast cell survival, proliferation, and constitutive activation: cooperative roles for CADM1, stem cell factor, and IL-6. J Immunol. 2008;181:2772-2780.

81. Tunon-de-Lara J-M, Berger $\mathrm{P}$, Bégueret $\mathrm{H}$. Mast cells in airway smooth muscle. N Engl J Med. 2002;347:1040-1041; author reply 1040-1041. https://doi.org/10.1056/NEJM200209263471318

82. Brightling CE, Bradding P, Symon FA, et al. Mast-cell infiltration of airway smooth muscle in asthma. N Engl J Med. 2002;346:16991705. https://doi.org/10.1056/NEJMoa012705

83. Fregonese L, Swan FJ, van Schadewijk A, et al. Expression of the anaphylatoxin receptors $\mathrm{C} 3 \mathrm{aR}$ and $\mathrm{C} 5 \mathrm{aR}$ is increased in fatal asthma. J Allergy Clin Immunol. 2005;115:1148-1154. https://doi. org/10.1016/j.jaci.2005.01.068

84. Sur S, Hunt LW, Crotty TB, Gleich GJ. Sudden-onset fatal asthma. Mayo Clin Proc. 1994;69:495-496. https://doi.org/10.1016/s0025 $-6196(12) 61651-6$

85. Burgel P-R, Lazarus SC, Tam D-W, et al. Human eosinophils induce mucin production in airway epithelial cells via epidermal growth factor receptor activation. J Immunol. 2001;167:5948-5954. https://doi.org/10.4049/jimmunol.167.10.5948

86. Persson EK, Verstraete K, Heyndrickx I, et al. Protein crystallization promotes type 2 immunity and is reversible by antibody treatment. Science. 2019;364(6442):eaaw4295. https://doi. org/10.1126/science.aaw4295

87. Zhang X, Zhang LI, Wang G, et al. Clinical phenotypes of patients hospitalized for an asthma exacerbation: prognostic implications. 
J Allergy Clin Immunol Pract. 2020. https://doi.org/10.1016/j. jaip.2020.09.031

88. Serrano-Pariente J, Rodrigo G, Fiz JA, et al. Identification and characterization of near-fatal asthma phenotypes by cluster analysis. Allergy. 2015;70:1139-1147. https://doi.org/10.1111/all.12654

89. GBD 2015 Chronic Respiratory Disease Collaborators. Global, regional, and national deaths, prevalence, disability-adjusted life years, and years lived with disability for chronic obstructive pulmonary disease and asthma, 1990-2015: a systematic analysis for the Global Burden of Disease Study 2015. Lancet Respir Med. 2017;5:691-706. https://doi.org/10.1016/S2213-2600(17)30 293-X

90. Salmeron S, Liard R, Elkharrat D, et al. Asthma severity and adequacy of management in accident and emergency departments in France: a prospective study. Lancet. 2001;358:629-635.

91. Marquette $\mathrm{CH}$, Saulnier $\mathrm{F}$, Leroy $\mathrm{O}$, et al. Long-term prognosis of near-fatal asthma. A 6-year follow-up study of 145 asthmatic patients who underwent mechanical ventilation for a near-fatal attack of asthma. Am Rev Respir Dis. 1992;146:76-81. https://doi. org/10.1164/ajrccm/146.1.76

92. Doshi V, Shenoy S, Ganesh A, et al. Near fatal asthma in an inner city population. Am J Ther. 2016;23:e1375-e1380. https://doi. org/10.1097/MJT.0000000000000152

93. Gonzalez Barcala FJ, Aboal Viñas J, Valdes Cuadrado L, et al. Trends in hospital admissions due to asthma in north-west Spain from 1995 to 2007. Allergol Immunopathol (Madr). 2010;38:254258. https://doi.org/10.1016/j.aller.2009.11.008

94. Ponte EV, Souza-Machado A, Souza-Machado C, et al. Clinical characteristics and prognosis in near-fatal asthma patients in Salvador, Brazil. J Bras Pneumol. 2011;37:431-437. https://doi. org/10.1590/s1806-37132011000400004

95. Tanaka H, Nakatani E, Fukutomi Y, et al. Identification of patterns of factors preceding severe or life-threatening asthma exacerbations in a nationwide study. Allergy. 2018;73:1110-1118. https:// doi.org/10.1111/all.13374

96. Aubas C, Bourdin A, Aubas P, et al. Role of comorbid conditions in asthma hospitalizations in the south of France. Allergy. 2013;68:637-643. https://doi.org/10.1111/all.12137

97. Brenner B, Corbridge T, Kazzi A. Intubation and mechanical ventilation of the asthmatic patient in respiratory failure. J Allergy Clin Immunol. 2009;124:S19-S28. https://doi.org/10.1016/j. jaci.2009.05.008

98. Bond KR, Horsley CA, Williams AB. Non-invasive ventilation use in status asthmaticus: 16 years of experience in a tertiary intensive care. Emerg Med Australas. 2018;30:187-192. https://doi. org/10.1111/1742-6723.12876

99. Peters JI, Stupka JE, Singh H, et al. Status asthmaticus in the medical intensive care unit: a 30-year experience. Respir Med. 2012;106:344-348. https://doi.org/10.1016/j.rmed.2011.11.015

100. Yamauchi $\mathrm{Y}$, Yasunaga $\mathrm{H}$, Matsui $\mathrm{H}$, et al. Comparison of in-hospital mortality in patients with COPD, asthma and asthma-COPD overlap exacerbations. Respirology. 2015;20:940-946. https://doi. org/10.1111/resp.12556
101. Kaur BP, Lahewala S, Arora S, et al. Asthma: Hospitalization Trends and Predictors of In-Hospital Mortality and Hospitalization Costs in the USA (2001-2010). Int Arch Allergy Immunol. 2015;168:71-78. https://doi.org/10.1159/000441687

102. Nowak RM, Parker JM, Silverman RA, et al. A randomized trial of benralizumab, an antiinterleukin 5 receptor $\alpha$ monoclonal antibody, after acute asthma. Am J Emerg Med. 2015;33:14-20. https:// doi.org/10.1016/j.ajem.2014.09.036

103. Tello K, Hoffmann A, Beutel B, et al. Anti-interleukin-5 therapy (mepolizumab) in life-threatening asthma attack: a case-based discussion. Respir Med Case Rep. 2019;28:100927. https://doi. org/10.1016/j.rmcr.2019.100927

104. Shrimanker R, Pavord ID, Yancey S, et al. Exacerbations of severe asthma in patients treated with mepolizumab. Eur Respir J. 2018;52: https://doi.org/10.1183/13993003.01127-2018

105. Ramakrishnan S, Camp JR, Vijayakumar B, et al. The use of benralizumab in the treatment of near fatal asthma: a new approach. Am J Respir Crit Care Med. 2020;201(11):1441-1443. https://doi. org/10.1164/rccm.202001-0093LE

106. Pérez de Llano L, Blanco Cid N, Ortiz Piquer M, Dacal Rivas D. Compassionate use of a single dose of benralizumab in a near-fatal asthma exacerbation. J Investig Allergol Clin Immunol. 2020;31(3). https://doi.org/10.18176/jiaci.0609

107. Bachert C, Han JK, Desrosiers M, et al. Efficacy and safety of dupilumab in patients with severe chronic rhinosinusitis with nasal polyps (LIBERTY NP SINUS-24 and LIBERTY NP SINUS-52): results from two multicentre, randomised, double-blind, placebo-controlled, parallel-group phase 3 trials. Lancet. 2019;394:1638-1650. https://doi.org/10.1016/S0140-6736(19)31881-1

108. Ferreira DS, Annoni R, Silva LFF, et al. Toll-like receptors 2, 3 and 4 and thymic stromal lymphopoietin expression in fatal asthma. Clin Exp Allergy. 2012;42:1459-1471. https://doi. org/10.1111/j.1365-2222.2012.04047.x

109. Groneberg DA, Eynott PR, Lim S, et al. Expression of respiratory mucins in fatal status asthmaticus and mild asthma. Histopathology. 2002;40:367-373. https://doi.org/10.1046/j. 1365-2559.2002.01378.x

110. Shiang C, Mauad T, Senhorini A, et al. Pulmonary periarterial inflammation in fatal asthma. Clin Exp Allergy. 2009;39:1499-1507. https://doi.org/10.1111/j.1365-2222.2009.03281.x

111. Den Otter I, Silva LFF, Carvalho ALN, et al. High-affinity immunoglobulin $\mathrm{E}$ receptor expression is increased in large and small airways in fatal asthma. Clin Exp Allergy. 2010;40:1473-1481. https:// doi.org/10.1111/j.1365-2222.2010.03576.x 